\title{
Understanding Personality Types and Multiple Intelligences of Hospitality and Tourism Management Graduating Students: Inputs to Skills Enhancement and Employability
}

\author{
Gener Santiago Subia1*, Michelle Escuadro Tangonan1, Nancy Mae Sanchez Ricio1, \\ Girlie Gaya Pascuall ${ }^{1}$, Roselia Nasino Nuñez ${ }^{1}$, Erlinda Cruz Mones ${ }^{2}$ \\ ${ }^{1}$ Faculty, College of Hospitality and Tourism Management, Wesleyan University-Philippines, Cabanatuan City, Philippines \\ ${ }^{2}$ Former Guidance Counselor, Wesleyan University-Philippines, Cabanatuan City, Philippines \\ Email: *subiagener@yahoo.com
}

How to cite this paper: Subia, G. S., Tangonan, M. E., Ricio, N. M. S., Pascual, G. G., Nuñez, R. N., \& Mones, E. C. (2022). Understanding Personality Types and Multiple Intelligences of Hospitality and Tourism Management Graduating Students: Inputs to Skills Enhancement and Employability. Open Journal of Business and Management, 10, 606-613.

https://doi.org/10.4236/ojbm.2022.102034

Received: January 16, 2022

Accepted: February 14, 2022

Published: February 17, 2022

Copyright $\odot 2022$ by author(s) and Scientific Research Publishing Inc. This work is licensed under the Creative Commons Attribution International License (CC BY 4.0).

http://creativecommons.org/licenses/by/4.0/

\begin{abstract}
The personality types and multiple intelligences of 108 randomly selected hospitality and tourism management graduating students from Wesleyan University Philippines were explored in this descriptive-correlational study. The findings revealed that the respondents were at the appropriate age to begin their professional careers. They were more relaxed, patient, and easy-going individuals. Bodily-kinesthetic, intrapersonal, and interpersonal intelligence were their top three intelligences, implying that they could excel as performers, salespeople, authors, skilled employees, and leaders. When they work in a firm that values collaboration and teamwork, they will perform better. Their personality types have nothing to do with their multiple intelligences.
\end{abstract}

\section{Keywords}

Employability, Hospitality and Tourism Management Students, Multiple Intelligences, Personality Types, Skills Enhancement

\section{Introduction}

One of the goals of the College of Hospitality and Tourism Management at Wesleyan University Philippines is to deliver excellent education to its students. To realize this, learners' demands, particularly their intelligence and personality, must be effectively recognized and handled so that they can be equipped with the needed skills and information for the real world of work.

Gardner described intelligence as multiple and different to each individual. $\mathrm{He}$ 
defines intelligence as a "biopsychological potential to process information that can be activated in a cultural setting to solve problems or create products that are of value in a culture" (Gardner, 2000: p. 28). While evaluating each "candidate" intelligence, Gardner devised a set of eight inclusion criteria based on a number of scientific areas. These are "linguistic intelligence, logical-mathematical intelligence, spatial intelligence, bodily-kinesthetic intelligence, musical intelligence, interpersonal intelligence, intrapersonal intelligence, and naturalistic intelligence" (Marenus, 2020). Gardner says "we all have these intelligences, but our particular profiles of these intelligences may differ based on genetics or experience". The researchers are one with Gardner in this idea and decided to dig deeper with the multiple intelligences of the hospitality and tourism management graduating students to help them improve their skills and be potential desirable employees. Further, to be able to understand job satisfaction in hotel management, graduating students must first discover which personality traits are required to attain the quality of service (Jovičić et al., 2011). Thus, understanding the Type A (competitive, time urgent, and hostile and aggressive) and Type B (relaxed, patient, and easy-going) personalities of the students, popularized by Meyer Friedman and RH Rosenman in the 1950s (McLeod, 2017) was also explored in this study. Understanding their learners better will guide the professors to offer the teaching styles (Subia et al., 2019) that their students deserve, consequently, leads to managing the students for skills enhancement and better opportunities for employment.

\section{Literature Review}

Recognizing and fostering all types of human intelligences is critical for students to discover their skills and identify different intelligences. According to studies, eliciting the full potential of intelligences leads to students' academic and future professions (Thambu, Prayitno, \& Zakaria, 2021). This statement is evident in the findings of Ahvan, Y. \& Pour, H. in 2016, regarding the "correlation of multiple intelligences for the achievements of secondary students". Their study revealed that "moderate inter-correlation exists between verbal-linguistic and visual-spatial intelligences and academic performance achievement $(p<.05)$. Multiple intelligences such as logical-mathematical, visual-spatial, verbal-linguistic, intrapersonal, bodily-kinesthetic, interpersonal and naturalistic have a significant positive relationship with academic performance achievement of students $(p<.05)$ ". Also, "for Barraza \& González’ study (2016), there are still correlations discovered between academic performance and intelligences of students: linguistic, logical-mathematical, as well as an inverse correlation with the attention branch of emotional intelligence; in this way, it shows no correlation with the other dimensions of emotional intelligence and multiple intelligences".

Further, gender differences were correlated by researchers in the multiple intelligences and found out that significant difference exists between the intelli- 
gences of male and female students (Şener \& Çokçalışkan, 2018; Swami, Furnham, \& Zilkha, 2009).

Additional variables were explored by authors to study correlates of multiple intelligences and established that: "there are some significant correlations between multiple intelligences, personality traits and critical thinking skills of high achievers from secondary schools of Mara Science College, Malaysia" (Lee et al., 2012); "relationships between graduate EFL learners' personality traits and multiple intelligences with their reading proficiency proved that various individuals have a tendency to do differently while reading and in spite of the different reading preferences, readers tend to be relatively consistent in their performance" (Sadeghi, Abusaeedi, \& Jafarigohar, 2019); "regression analysis of Barraza \& González' (2016), indicated that participants believed verbal, logical-mathematical, and spatial intelligence to be the main predictors of intelligence", and; for Şener \& Çokçalışkan (2018), the three intelligence groups with highest academic achievement in their study and considered intellectual individuals were: "Naturalistic, Visual-Spatial and Bodily-Kinesthetic intelligences types".

\section{Methodology}

This study investigated the interrelationships that exist among the profile of the Hospitality and Tourism Management graduating students, their multiple intelligences, and their personality types based on Gardner's multiple intelligences theory and Meyer Friedman and RH Rosenman personality types. This study is a descriptive-correlational research design. A total of 148 students were enrolled in the college and with the use of Raosoft sample size calculator, 108 students were selected as sample respondents of this study. The students were picked using simple random sampling technique. Two types of research instruments were utilized in this study. The first is an online multiple intelligence test created by literacynet.org.

(https://www.literacynet.org/mi/assessment/findyourstrengths.html) and the researcher-made instrument where the profile and personality types of the graduating students were written and assessed with the help of guidance counselors. They had spent more than 15 years as guidance counselors and faculty advisers, so they were specialists in student personality types. They are currently employed as the Gender and Development Director and Coordinator at their respective universities. Statistical tools that were utilized in this study were frequency, percentage, rank, weighted mean, Pearson's r, and Spearman's rho.

\section{Results and Discussion}

\subsection{Socio-Demographic Profile of the Respondents}

Table 1 shows the profile of the hospitality and tourism management graduating students in terms of age, sex, birth order, and family monthly income.

The data revealed that almost $93 \%$ of the graduating students were in the age range of $20-21$ and 22 to 23 , more than $60 \%$ of them were females. This 
Table 1. Profile of the respondents.

\begin{tabular}{|c|c|c|}
\hline Age & Frequency & Percent \\
\hline 20 to 21 & 62 & 57.41 \\
\hline 22 to 23 & 38 & 35.19 \\
\hline 24 to 25 & 6 & 5.56 \\
\hline 26 to 27 & 2 & 1.85 \\
\hline Total & 108 & 100.00 \\
\hline Sex & Frequency & Percent \\
\hline Male & 42 & 38.89 \\
\hline Female & 66 & 61.11 \\
\hline Total & 108 & 100.00 \\
\hline Birth Order & Frequency & Percent \\
\hline 0 to 1 & 40 & 37.04 \\
\hline 2 to 3 & 56 & 51.85 \\
\hline 4 to 5 & 11 & 10.19 \\
\hline 6 and above & 1 & 0.93 \\
\hline Total & 108 & 100.00 \\
\hline Family Monthly Income & Frequency & Percent \\
\hline P50,000 to less than 100,000 & 85 & 78.70 \\
\hline $\mathrm{P} 100,000$ to less than 150,000 & 19 & 17.59 \\
\hline $\mathrm{P} 150,000$ to less than 200,000 & 3 & 2.78 \\
\hline P200,000 to less than 250,000 & 1 & .93 \\
\hline Total & 108 & 100.00 \\
\hline
\end{tabular}

signifies that the respondents past their adolescence stage and are now in their adulthood which is a "phase of optimum mental functioning when the individual's intellectual, emotional, and social capabilities are at their best to handle the responsibilities of careers and even their marriage, and their children", particularly the females (The Editors of Encyclopedia Britannica, n.d.).

As to their birth order, it can be seen in Table 1 that most were in the $2^{\text {nd }}$ and third child position and have a family monthly income of P50,000 (\$1000) to P100,000 (\$2000). In other words, the respondents' families were middle-income earners who earned between four and seven times the poverty limit in the Philippines (Zoleta, 2021) and therefore, can afford to take one of the country's expensive courses.

\subsection{Personality Types of the Respondents}

Table 2 presents the personality types of the tourism and hospitality management 
Table 2. Personality types of the respondents.

\begin{tabular}{ccc}
\hline Personality Types & Frequency & Rank \\
\hline Type A & 42 & 2 \\
Type B & 66 & 1 \\
Total & 108 & \\
\hline
\end{tabular}

graduating students as to type A and type B traits. According to McLeod (2017), the Type A people are competitive, time urgent, hostile and aggressive while Type $B$ are relaxed, patient, and easy-going individuals.

Type B personality was dominant among the respondents. This means that they are calm, tolerant, and easy-going individuals. Because of their relaxed attitude, the respondents have a tendency to procrastinate and score lower than Type A in three main areas of the Jenkins Activity Survey: job involvement, competitiveness, and impatience (Green, Meagher, \& Millon, 2012).

\subsection{Multiple Intelligence of the Respondents}

Table 3 reveals the dominant multiple intelligences of the tourism and hospitality management graduating students in terms of bodily-kinesthetic, linguistic, logical-mathematical, musical, intrapersonal, interpersonal, spatial, and naturalistic.

The top 3 intelligences of the respondents were bodily-kinesthetic, intrapersonal, and interpersonal. "People who are bodily-kinesthetic are said to be good at body movement, performing actions, and physical control and tend to have excellent hand-eye coordination and dexterity" (Singh et al., 2017). Intrapersonal intelligent individuals, on the other hand, "are inclined to enjoy self-reflection and analysis, including daydreaming, exploring relationships with others, and assessing their personal strengths" (Sternberg, 2012). While interpersonal people are "good at understanding and interacting with other people, can create positive relationships with others and can resolve conflicts in group settings" (Sternberg, 2012). This implies that the hospitality and tourism management graduating students can thrive in jobs that showcase performances and skills. Further, they can excel as salespersons and can become excellent writers, team workers, and leaders.

\subsection{Interrelationships among the Profile, Personality Types, and Multiple Intelligences of the Respondents}

Table 4 discloses the relationships that exist among the three major variables explored in this study.

Only the profile age $(\mathrm{r}=-.236, p<.05)$ had a significant link with personality types, as seen in the table. It suggests that type B people were more prevalent among the younger respondents. There was no correlation between any of the profile characteristics and multiple intelligence. In addition, the respondents' 
Table 3. Multiple intelligence of the respondents.

\begin{tabular}{ccc}
\hline Multiple Intelligence & Frequency & Rank \\
\hline Body Movement (Bodily-Kinesthetic Intelligence) & 25 & 1 \\
Language (Linguistic Intelligence) & 7 & 7 \\
Math (Logical-Mathematical Intelligence) & 8 & 6 \\
Musical (Musical Intelligence) & 13 & 2 \\
Self (Intrapersonal Intelligence) & 24 & 3 \\
Social (Interpersonal Intelligence) & 17 & 8 \\
Spatial (Visual-Spatial Intelligence) & 4 & 5 \\
Nature (Naturalistic Intelligence) & 10 & 5
\end{tabular}

Table 4. Interrelationships among the profile, personality types and multiple intelligences of the respondents.

\begin{tabular}{ccccccc}
\hline Profile & Personality Types & $p$-value & Interpretation & Multiple Intelligences & $p$-value & Interpretation \\
\hline Age & $-.236^{*}$ & .014 & SR & -.158 & .102 & NSR \\
Sex & -.073 & 108 & NSR & .087 & .371 & NSR \\
Birth Order & .023 & .817 & NSR & .057 & .557 & NSR \\
Family Monthly Income & .103 & .467 & NSR & .034 & .808 & NSR \\
Multiple Intelligences & .067 & .491 & NSR & & & \\
\hline
\end{tabular}

Legend: SR-Significant Relationship; NSR-No Significant Relationship.

personality types and multiple intelligence were not shown to be significantly connected. This suggests that the respondents' characteristics are unrelated to their intelligences. This study contradicts Lee et al.'s finding, which found some substantial relationships between multiple intelligences and student personality attributes (Lee et al., 2012).

\section{Conclusions and Recommendations}

The respondents were at the ideal age to begin their careers as performers, salespeople, writers, employees, and leaders, according to the survey. They were more stress-free and have a tendency to procrastinate. They will do better in a company that encourages collaboration and teamwork. Their traits are unrelated to their multidimensional intelligence in any way. They were more of interpersonal and bodily-kinesthetic individuals. Short language trainings for multicultural diversity should be introduced by the College of Hospitality and Tourism Management and incorporated into courses like Asian cooking, French cuisine, FNB service, and others to help strengthen the students' interpersonal skills and widen their vocabulary. Laboratory trainings and workshops for new approaches could be provided by the CHTM with the support of their specialists' alumni who are well-known in the field of tourism and hospitality sector for students' 
bodily-kinesthetic growth.

\section{Limitations of the Study}

The results of this research cannot be generalized to the whole population of students enrolled in tourism and hospitality management of the whole city since only one school was covered in this study. Similarly, this study only looked at eight different intelligences. Future researchers who pursue this line of inquiry should think about the last intelligence, the existential intelligence.

\section{Conflicts of Interest}

The authors declare no conflicts of interest regarding the publication of this paper.

\section{References}

Ahvan, Y., \& Pour, H. (2016). The Correlation of Multiple Intelligences for the Achievements of Secondary Students. Educational Research and Reviews, 11, 141-145. https://doi.org/10.5897/ERR2015.2532

Barraza, R., \& González, M. (2016) Rendimiento académico y autopercepción de inteligencias múltiples e inteligencia emocional en universitarios de primera generación. Revista Actualidades Investigativas en Educación, 16, 1-23. https://doi.org/10.15517/aie.v16i2.23930

Gardner, H. E. (2000). Intelligence Reframed: Multiple Intelligences for the 21st Century. Hachette UK.

Green, C., Meagher, R., \& Millon, T. (Eds.) (2012) Handbook of Clinical Health Psychology. Plenum Press.

Jovičić, A., Milanović, T., Todorović, M., \& Vujičić, D. (2011). The Importance of Fitting Personality Dimensions and Job Characteristics in Employees in the Hotel Management. Turizam, 15, 119-131. https://doi.org/10.5937/Turizam1103119J

Lee, M., Shariffudin, R. S., \& Mislan, N. (2012). Pattern and Relationship between Multiple Intelligences, Personality Traits and Critical Thinking Skills among High Achievers in Malaysia. International Proceedings of Economics Development \& Research, 27, 205-209. https://www.semanticscholar.org/paper/Pattern-and-Relationship-Between-Multiple-T raits-in-Lee-Shariffudin/32d8f9663898aa2b7bf47237b428d4ea01732f1e

Marenus, M. (2020, June 9). Gardner's Theory of Multiple Intelligences. https://www.simplypsychology.org/multiple-intelligences.html

McLeod, S. A. (2017). Type A Personality. Simply Psychology. https://www.simplypsychology.org/personality-a.html

Sadeghi, N., Abusaeedi, A., \& Jafarigohar, M. (2019). Personality Traits and Multiple Intelligences as Predictors of Reading Proficiency among Iranian EFL Learners. Journal of Language and Translation, 9, 101-120.

Şener, S., \& Çokçalışkan, A. (2018). An Investigation between Multiple Intelligences and Learning Styles. Journal of Education and Training Studies, 6, 125-132.

https://doi.org/10.11114/jets.v6i2.2643 http://jets.redfame.com

Singh, Y., Makharia, A., Sharma, A., Agrawal, K., Varma, G., \& Yadav, T. (2017). A Study on Different Forms of Intelligence in Indian School-Going Children. Industrial Psychiatry 
Journal, 26, 71-76.

Sternberg, R. J. (2012). Intelligence. Dialogues in Clinical Neuroscience, 14, 19-27. https://doi.org/10.31887/DCNS.2012.14.1/rsternberg

Subia, G., Trinidad, C., Pascual, R., Medrano, H. \& Manuzon, E. (2019). Learning Styles and Preferred Teaching Styles of Master of Arts in Teaching (MAT), Major in Vocational Technological Education (VTE) Generation Y Learners. International Journal of English Literature and Social Sciences, 4, 431-436.

https://doi.org/10.22161/ijels.4.2.35

Swami, V., Furnham, A., \& Zilkha, S. (2009). Estimates of Self, Parental, and Partner Multiple Intelligence and Their Relationship with Personality, Values, and Demographic Variables: A Study in Britain and France. Spanish Journal of Psychology, 12, 528-539. https://doi.org/10.1017/S1138741600001906

Thambu, N., Prayitno, H. J., \& Zakaria, G. A. N. (2021). Incorporating Active Learning into Moral Education to Develop Multiple Intelligences: A Qualitative Approach. Indonesian Journal on Learning and Advanced Education, 3, 17-29.

https://doi.org/10.23917/ijolae.v3i1.10064

The Editors of Encyclopedia Britannica. (n.d.). Psychological Development. https://www.britannica.com/science/psychological-development

Zoleta, V. (2021, January 12). Understanding Social Class in the Philippines: Which Class Do You Belong to?

https://www.moneymax.ph/personal-finance/articles/social-class-philippines 